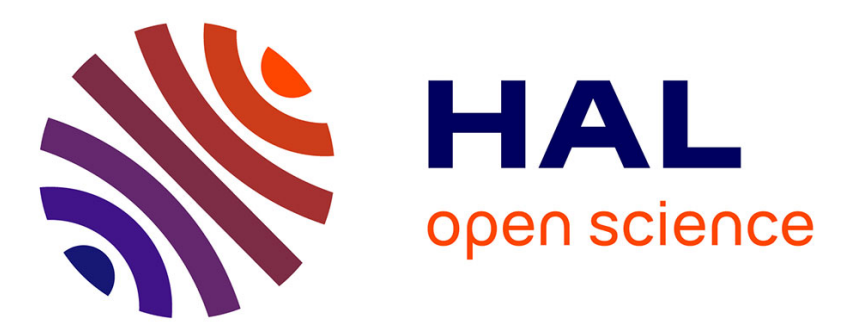

\title{
A Case Study on the Evolution of Chinese Religious Symbols from Talismanic Paraphernalia to Taoist Liturgy
}

\author{
Grégoire Espesset
}

\section{- To cite this version:}

Grégoire Espesset. A Case Study on the Evolution of Chinese Religious Symbols from Talismanic Paraphernalia to Taoist Liturgy. Bulletin of the School of Oriental and African Studies, 2015, 78 (3), pp.493-514. 10.1017/S0041977X15000439 . halshs-01385139

\section{HAL Id: halshs-01385139 \\ https://shs.hal.science/halshs-01385139}

Submitted on 7 Dec 2021

HAL is a multi-disciplinary open access archive for the deposit and dissemination of scientific research documents, whether they are published or not. The documents may come from teaching and research institutions in France or abroad, or from public or private research centers.
L'archive ouverte pluridisciplinaire HAL, est destinée au dépôt et à la diffusion de documents scientifiques de niveau recherche, publiés ou non, émanant des établissements d'enseignement et de recherche français ou étrangers, des laboratoires publics ou privés. 


\section{Bulletin of the School of Oriental and African Studies}

http://journals.cambridge.org/BSO

Additional services for Bulletin of the School of Oriental and African Studies:

Email alerts: Click here

Subscriptions: Click here

Commercial reprints: Click here

Terms of use : $\underline{\text { Click here }}$

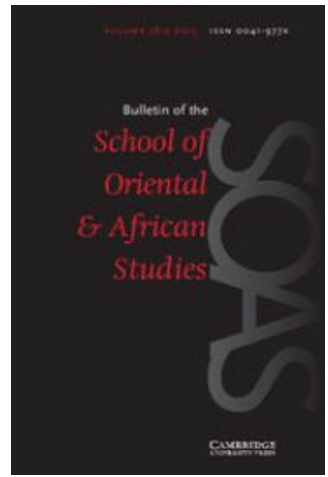

\section{A case study on the evolution of Chinese religious symbols from talismanic paraphernalia to Taoist liturgy}

Grégoire Espesset

Bulletin of the School of Oriental and African Studies / Volume 78 / Issue 03 / October 2015, pp $493-514$

DOI: 10.1017/S0041977X15000439, Published online: 16 June 2015

Link to this article: http://journals.cambridge.org/abstract_S0041977X15000439

How to cite this article:

Grégoire Espesset (2015). A case study on the evolution of Chinese religious symbols from talismanic paraphernalia to Taoist liturgy. Bulletin of the School of Oriental and African Studies, 78, pp 493-514 doi:10.1017/S0041977X15000439

Request Permissions : $\underline{\text { Click here }}$ 


\title{
A case study on the evolution of Chinese religious symbols from talismanic paraphernalia to Taoist liturgy
}

\author{
Grégoire Espesset $^{1}$
}

Centre de recherche sur les civilisations de l'Asie Orientale (CRCAO), Paris gresp@yahoo.com

\begin{abstract}
The mid-fifteenth-century Taoist Canon (Zhengtong daozang 正統道藏) contains five specimens of a religious artefact called "Great Peace Symbol" ("Taiping fu" 太平符), dispersed between five texts spanning about a millennium. The introduction to this paper discusses the meaning of the Chinese word $f u$ 符 and its most widely used English rendition, "talisman". The article briefly presents the source of each specimen, attempts a deconstruction of its morphology, and analyses its modus operandi, thus providing a basic methodological model to outline the historical evolution of the category of " $f u$ " artefacts from early medieval portable devices endowed with specific apotropaic functions - like charms and amulets - to multipurpose ritual implements designed for use within the framework of early modern Taoist liturgy. The epilogue introduces a sixth specimen, differently named but morphologically and functionally related to the latest three "Great Peace Symbols".
\end{abstract}

Keywords: Taoism, Visual material, Symbol, Talisman, Great Peace (Taiping), Liturgy

This is a study of five specimens from a group of religious visual artefacts spanning about a millennium in Chinese history and coming from sources included in the Taoist Canon (Zhengtong daozang 正統道藏), a mid-fifteenth-century collection of about 1,500 texts of various origins and representing various traditions. ${ }^{2}$ All five specimens are called "Great Peace Symbol" ("Taiping fu" 太平符). By briefly introducing the source of each specimen, describing its morphology and discussing its use, I hope to improve our

1 An early draft of this work was presented at the 48th International Congress on Medieval Studies, West Michigan University, Kalamazoo, 9-12 May 2013, Session 497 "Exorcism and other magical practices in medieval China". The author hereby expresses his gratitude to the Societas Magica for sponsoring that session, to Dimitri Drettas for organizing it, and to the anonymous referee who later helped improve the version submitted for publication.

2 For introductory remarks on visual materials in the Taoist Canon, see Franciscus Verellen, "The dynamic design: ritual and contemplative graphics in Daoist scriptures", in Benjamin Penny (ed.), Daoism in History: Essays in Honour of Liu Ts'un-yan (London and New York: Routledge, 2006), 159-86. 
knowledge of the category of artefact to which they belong, the $f u$ 符, and of some facets of its historical evolution.

\section{A foreword on terminology}

In his Explanation of Graphs and Analysis of Characters (Shuowen jiezi 說文解 字), the first Chinese graphological dictionary, completed by $100 \mathrm{AD}$, the Chinese scholar and official $\mathrm{Xu}$ Shen 許慎 gave the following definition of the word $f u:^{3}$

\section{符, 信也. 漢制以竹長六寸, 分而相合.}

$F u$ is a credential. [According to] Han [漢 dynasty (206 BC-220 AD)] institutions, it is made of bamboo, six inches in length, and divided [into two halves], which are then joined to one another [for the purpose of authentication]. ${ }^{4}$

The word $f u$ thus originates in administrative language, where it refers to an official document split in two matching halves and used for authentication. ${ }^{5} \mathrm{~A}$ recent synthetic approach to archaeological and transmitted materials suggests that the device mostly served bureaucratic and military functions. It was used as a certificate to authenticate a liaison officer, or as a passport to cross passes and outposts or to enter the imperial capital. ${ }^{6}$ To some extent, it may be compared to what the Romans called tessera. ${ }^{7}$

We find the word used in the context of political legitimacy by the founding of the first Chinese Empire. Especially when combined with another word, ming 命 (a "mandate"), it refers to a token of sovereignty sent by heaven to legitimize a new emperor. ${ }^{8}$ By the second century of our era at the latest, the word was

3 For the date of the original version of this work submitted to the throne in 121 , see William G. Boltz, “Shuo wen chieh $t z u$ 說文解字”, in Michael Loewe (ed.), Early Chinese Texts: A Bibliographical Guide (Berkeley: Society for the Study of Early China, 1993), 429-42. My translation of the title derives from Françoise Bottéro, "Revisiting the wen 文 and the $z i$ 字: the great Chinese characters hoax", Bulletin of the Museum of Far Eastern Antiquities, 74, 2002, 14-33.

4 Shuowen jiezi: fu jianzi 說文解字 附檢字 (Beijing: Zhonghua shuju, 1963), 95.

5 The classic introduction to the phenomenology of $f u$ remains the first two sections of Robert des Rotours, "Les insignes en deux parties ( $f o u$ 符) sous la dynastie T'ang (618-907)", T'oung Pao, 41/1-3, 1952, 1-148.

6 Stephan Peter Bumbacher, Empowered Writing: Exorcistic and Apotropaic Rituals in Medieval China (St Petersburg, FL: Three Pines Press, 2012), 13-31. Bumbacher contrasts $f u$ with three other types of authentication documents split into two parts or more: jie 節 (originally a "bamboo nod"), used by travelling merchants for taxation exemption; quan 券 (a "contract"), split between creditors and debtors to ensure financial transactions; and $q i$ 契 (a "tally"), used for credit purposes by local officials accompanying foreign diplomats.

7 William Lewis (ed.), Dictionary of Greek and Roman Antiquities (Boston: Little, Brown, and Co., 1859), 1112b-13a.

8 See Max Kaltenmark, "Ling-pao 靈寶: Note sur un terme du taoïsme religieux", Mélanges publiés par l'Institut des hautes études chinoises (Paris: Presses Universitaires de France, 1960), 2, 559-88; Jack L. Dull, “A historical introduction to 
imported into the religious lexicon where, while retaining its earlier basic meanings, it soon came to be defined as a cosmic credential and a heavenly graph or pattern. ${ }^{9}$ But the idea that "gods matched the 'earthly' parts with their 'heavenly' part of the $f u$ [and, if] both parts tallied exactly ... were prepared to listen" to the priests asking them for help, seems to be a late interpretation not confirmed by textual evidence. ${ }^{10}$ This interpretation echoes a statement by Anna Seidel, which is not supported by the source to which she refers. ${ }^{11}$

In practice, these early medieval religious artefacts were esoteric figures and writings of varying complexity, drawn by specialists on specific media using special inks or powders, and endowed with various powers (some examples of which we shall discuss below). ${ }^{12}$ Their use was not restricted to the Taoists. Rather, they were quite common among other religious traditions, including popular cults and Buddhism. ${ }^{13}$

the apocryphal (Ch'an-wei) texts of the Han Dynasty", $\mathrm{PhD}$ dissertation, University of Washington (Seattle, 1966), 160-62; Bumbacher, Empowered Writing, 46-53.

9 For a survey of this transition process, see pp. 310-16 of Anna Seidel, "Imperial treasures and Taoist sacraments: Taoist roots in the Apocrypha", in Michel Strickmann (ed.), Tantric and Taoist Studies in Honour of R.A. Stein, 2 (Brussels: Institut Belge des Hautes Études Chinoises, 1983), 291-371. A ternary periodization of Taoist symbols in the imperial era has been proposed by Wang Yucheng 王育成, “Wenwu suo jian Zhongguo gudai dao fu shulun” 文物所見中國古代道符述論, Daojia wenhua yanjiu 道家文化研究, 9, 1996, 267-301. Our specimens would fit in Wang's first and second developmental periods, namely gradual formalization (third-sixth century) - first specimen - then apex, diversification, and transnational diffusion (seventh-nineteenth century) - second to fifth specimens.

10 Quoting Bumbacher, Empowered Writing, 80.

11 Seidel, "Imperial treasures and Taoist sacraments", 311: "The ruler (chün-tzu) reaches to what is above, he joins tallies (ho-fu) with Heaven". In a footnote, Seidel refers to a citation of a Weft (wei 緯) text, without quoting it. Found in Yasui Kōzan 安居香山 and Nakamura Shōhachi 中村璋八 (eds), Jūshū Isho shūsei, 5, Kōkyō-Rongo 重修緯書集 成 卷五 孝經・論語 (Tokyo: Meitoku shuppansha, 1973), 117, first item, this citation reads: “君子上達, 與天合符”. Its source is the Anthology of Literature (Wenxuan 文選), compiled between 526 and 531 by Xiao Tong 蕭統 (501-531), "Inscription for the new Clepsydra" (“Xin louke ming” 新漏刻銘), 56.32a (Siku quanshu edition). It appears in Li Shan's 李善 (630-689) commentary to the following couplet: 況入神之制, 與造化合 符/成物之能, 與坤元等契. The disyllables hefu 合符 and dengqi 等契 therein are syntactically parallel and semantically equivalent. Both verb-object compounds function as verbs meaning "to match perfectly" or "to tally with". The same goes for hefu in the citation, which may be translated as: "The gentleman reaches upwards and matches Heaven perfectly". Shu-wei Hsieh, "Writing from heaven: celestial writing in Six Dynasties Daoism", PhD dissertation, Indiana University, Bloomington, 2005, 80-81, repeats the mistake.

12 For various reproductions of such artefacts, see Laszlo Legeza, Tao Magic: The Chinese Art of the Occult (London: Thames and Hudson, 1975), 31-127; Monika Drexler, Daoistische Schriftmagie: Interpretationen zu den Schriftamuletten Fu im Daozang (Stuttgart: Franz Steiner, 1994); Catherine Despeux, "Talismans and sacred diagrams", in Livia Kohn (ed.), Daoism Handbook (Leiden: Brill, 2000), 498-540; Christine Mollier, "Talismans", in Marc Kalinowski (ed.), Divination et société dans la Chine médiévale: Étude des manuscrits de Dunhuang de la Bibliothèque nationale de France et de la British Library (Paris: Bibliothèque nationale de France, 2003), 405-29.

13 For comparative studies of Taoist and Buddhist artefacts, see Xiao Dengfu 蕭登福, Daojiao xingdou fuyin yu Fojiao mizong 道教星斗符印與佛教密宗 (Taipei: 
$F u$ was first translated as "magic sign", "charm", or "talisman" in modern Western sources. ${ }^{14}$ John Lagerwey argued convincingly that the Chinese word shares several meanings both with the current English word "symbol" and its root word $\sigma \dot{u} \mu \beta O \lambda o v$ in Greek. ${ }^{15}$ Nevertheless, "talisman" imposed itself among students of Taoism. A first problem with "talisman" is that it corresponds only to one of the historical meanings of the Chinese word, and not even the original one. ${ }^{16}$ The same may be said of "charm", also frequently encountered. In particular, both terms fail to render the earlier meanings of "tessera" and "token". A second problem is that some talismans were called "diagram" (tu 圖), “seal” (yin 印) or “seal imprint" (yinwen 印文), not $f u$ at all. ${ }^{17}$ To complicate the matter further, modern Chinese scholars have used the word $f u$ in connection with various funerary artefacts, some - but not all - of which bear inscriptions containing the character $f u$ or identified variants of it. ${ }^{18}$ This modern use has misled some Western scholars into calling the legal documents themselves " $f u$ " or "talismans": 19 their primary purpose was to protect surviving relatives

Xinwenfeng, 1993); Michel Strickmann (Bernard Faure, ed.), Chinese Magical Medicine (Stanford: Stanford University Press, 2002), 123-93; Christine Mollier, Buddhism and Taoism Face to Face: Scripture, Ritual, and Iconographic Exchange in Medieval China (Honolulu: University of Hawai' $i$ Press, 2008), 87-9 and 123-32. Further examples of Buddhist artefacts are presented and discussed in James Robson, "Signs of power: talismanic writing in Chinese Buddhism", History of Religions, 48/2, 2008, 130-69.

14 Henri Doré (1859-1931) used both "talisman" and "charme" in his Recherches sur les superstitions en Chine, 5, La lecture des talismans chinois: Explication de ceux qui ont paru dans la première partie des Recherches (Shanghai: Imprimerie de la Mission catholique, 1913). Édouard Chavannes (1865-1918) used "signe magique" in "Le Jet des dragons", in Émile Senart and Henri Cordier (eds), Mémoires concernant l'Asie Orientale (Inde, Asie Centrale, Extrême-Orient) publiés par l'Académie des Inscriptions et Belles-Lettres (Paris: Ernest Leroux, 1919), 3, 53-220. Henri Maspero (1882-1945) used "charme" (but "talisman" for $l u$ 籛) in Le Taoïsme et les religions chinoises (Paris: Gallimard, 1971). Max Kaltenmark (1910-2002) used "talisman" in "Les Tch'an-wei", Han-Hiue: Bulletin du Centre d'Études Sinologiques de Pékin, 2/4, 1949, 363-73. Isabelle Robinet (1932-2000) alternated "charme" and "talisman" in her Méditation taoïste (Paris: Dervy, 1979), 37-57.

15 John Lagerwey, Taoist Ritual in Chinese Society and History (New York: Macmillan, 1987), 155. In a private communication, Lagerwey explains that he was behind the use of "symbol" in Schipper's earlier Le Corps taoïste: Corps physique - corps social (Paris: Fayard, 1982), although Lagerwey's inspiration is not acknowledged in that book.

16 Gil Raz, The Emergence of Daoism: Creation of Tradition (Abingdon: Routledge, 2012), 134 , confuses the different meanings of $f u$ according to contexts and eras when stating that "early $f u$ were bipartite talismans".

17 For examples of Taoist talismans called "seals" (yin), see Drexler, Daoistische Schriftmagie, 38-9; Liu Hexin 劉合心 and He Jianwu 何建武, “Daojiao fuyin jiedu (1)” 道教符印解讀 (一), Wenbo 文博, 4, 2006, 20-23; Liu Hexin, “Daojiao fuyin jiedu (2)” 道教符印解讀 (二), Wenbo, 5, 2006, 49-52.

18 The most complete study of those funerary artefacts seems to be Zhang Xunliao 張勛燎, “Dong Han muzang chutu jiezhu qi he Tianshi dao de qiyuan” 東漢墓葬出土解注器和 天師道的起源, in Zhang Xunliao and Bai Bin 白涁, Zhongguo Daojiao kaogu 中國道 教考古 (Beijing: Xianzhuang shuju, 2006), 1; 2, 307-31.

19 Cases in point include Monika Drexler, "Schriftamulette $f u$ aus zwei Grabvasen der östlichen Han-Zeit", Monumenta Serica, 49, 2001, 227-48; Sakade Yoshinobu, 
from harm by placing the deceased under the jurisdiction of the otherworldly bureaucracy. ${ }^{20}$

This case study confirms that "talisman" cannot be used indiscriminately in Western publications as a rendition of the Chinese word " $f u$ ". Simply put, some talismans are not called $f u$ and some artefacts called $f u$ are not talismans. The two groups overlap, but they are not identical. Therefore, "symbol", despite its own limitations as a translation, seems more appropriate when referring to the category of $f u$ as a whole, and "talisman" should be reserved for relevant cases only.

\section{1. "Li Er's Great Peace Symbol” (fourth century)}

The first specimen comes from a work by Ge Hong 葛洪 (283-343) - an erudite man of Southern China who was involved in alchemy, medicine, and longevity practices - known as the Master Who Embraces Simplicity (Baopu zi 抱朴子). Composed during the first quarter of the fourth century, its final version dates to about $330 \mathrm{AD}^{21}$ It is a unique testimony to the religious traditions existing in the regions to the south of the River Yangtze, prior to the penetration of the Taoist Church - the Way of the Heavenly Master (Tianshi dao 天師道) - and the Taoist revelations of Upper Clarity (Shangqing 上清) and Numinous Treasure (Lingbao 靈寶) in the mid-fourth and early fifth centuries. ${ }^{22}$ The "inner chapters" (neipian 内篇) of this work give symbols an important role as prophylactic and apotropaic tools for resisting plague effects and avoiding death, especially in combination with a strict observance of prohibitions, and also as a means of perceiving a category of numinous minerals. ${ }^{23}$

In a chapter devoted to the experiences of anchorites, Ge Hong introduces eighteen symbols used by travellers and hermits to ward off wilderness-specific

Taoism, Medicine and Qi in China and Japan (Osaka: Kansai University Press, 2007), 69-86; and Bumbacher, Empowered Writing, 58-9.

20 That $f u$ elements were only one part of the phenomenology of funerary artefacts had been made clear by Anna Seidel on pp. 708-12 of her "Traces of Han religion in funeral texts found in tombs", in Akizuki Kan'ei 秋月觀暎 (ed.), Dōkyō to shūkyō bunka 道教と宗 教文化 (Tokyo: Hirakawa shuppansha, 1987), 678-714.

21 Kristofer Schipper and Franciscus Verellen (eds), The Taoist Canon: A Historical Companion to the Daozang (Chicago: The University of Chicago Press, 2004) [hereafter Companion], 70-71, no. 1185.

22 For a contextualization of the early development of Taoist communalism, see Grégoire Espesset, "Latter Han religious mass movements and the early Daoist church", in John Lagerwey and Marc Kalinowski (eds), Early Chinese Religion. Part One: Shang through Han (1250 BC-220 AD) (Leiden: Brill, 2009), 1061-102. For the situation of the Taoist Church in Ge Hong's time, and in the area with which he was most familiar, see Peter Nickerson, "The Southern celestial masters", in Kohn (ed.), Daoism Handbook, 256-82. On Upper Clarity Taoism, born of the rapid success of the Taoist Church among the Southern élite clans, see Isabelle Robinet, La révélation du Shangqing dans l'histoire du taoïsme (Paris: École Française d'Extrême-Orient, 1984), 2 vols. For a survey of Numinous Treasure Taoism during the medieval era, see Yamada Toshiaki, "The Lingbao School", in Kohn (ed.), Daoism Handbook, 225-55.

23 James R. Ware, Alchemy, Medicine, Religion in the China of A.D. 320: The Nei P'ien of Ko Hung (Pao-p'u tzu) (Cambridge, MA: Massachusetts Institute of Technology, 1966), 103, 164, 179 and 260. 
hazards. Some, which are worn, are, correctly speaking, talismans; others, magical signs to be placed inside the footsteps of wild beasts to divert their route. In addition, all of them can be affixed to beams or columns inside buildings. Illustrations are provided. ${ }^{24}$ The first seven symbols and the last of the series are called "Lord Lao's symbol for entering mountains" (“Laojun rushan fu” 老君入山符) by reference to perhaps the most renowned patron saint of Taoism, the deified Laozi 老 子. ${ }^{25}$ The eighth and ninth are called "Symbols to avoid tigers and wolves [when] entering mountains" (“Rushan pi hulang fu” 入山辟虎狼符). The tenth one, called "Symbol carried by Lord Lao" ("Laojun suo dai fu” 老君所戴符), is said to be efficient against ghosts, snakes, tigers, wolves, and spirits. The next three are "Symbols to hang to [one's] belt [when] entering mountains" (“Rushan peidai fu" 入山佩帶符). The last four are thus introduced:

\section{或用七星虎步及玉神符, 八威五勝符, 李耳太平符, 中黃華蓋印文及石} 流黃散, 燒牛羊角. 或立西岳公禁山符. 皆有驗也.

Some use the Tiger Pace of the Seven Stars ${ }^{26}$ along with the Jade God Symbol, the Symbol of the Eight Awe-Inspiring Ones ${ }^{27}$ and Five Conquests, ${ }^{28}$ Li Er's Great Peace Symbol, ${ }^{29}$ a print from the Seal of the Sumptuous Canopy ${ }^{30}$ of the Central Yellow as well as sulphur powder and a burned bovid horn. Others set up the Symbol of the Duke of the Western Peak ${ }^{31}$ Prohibiting Mountain [Access]. All prove effective. ${ }^{32}$

24 CT 1185, 17.14a-22b. [The acronym "CT" and attached numbering refer to K.M. Schipper et al., Concordance du Tao-tsang: Titre des ouvrages (Paris: École Française d'Extrême-Orient, 1975)]. Translated in Ware, Alchemy, Medicine, Religion, 279-300.

25 On this deification process, see Anna Seidel, La Divinisation de Lao tseu dans le taoïsme des Han (Paris: École Française d'Extrême-Orient, 1969).

26 The seven stars (qixing 七星) are those of the Northern Dipper (Ursa Major) constellation, on which, see below.

27 Bawei 八威, a series of eight awe-inspiring animals (tiger, leopard) and supernatural beings (unicorn, dragon and spirits), or gods related to the eight trigrams.

28 Wusheng 五勝, probably an allusion to the succession cycle of the Five Agents (wuxing 五行) by “mutual conquest" (xiangsheng 相勝).

$29 \mathrm{Li}$ Er 李耳 is the name of Laozi in the biography Sima Qian 司馬遷 $(145 / 135-86 / 87$ BC) devoted to him in Records of the Historiographer (Shiji 史記), 63.2139 (Zhonghua shuju edition). First known as Lao Dan 老聑, Laozi was renamed Li 李 (a clan allied to the Liu 劉) under the Han.

30 Huagai 華蓋, a constellation comprising seven stars from the Western Cassiopeia; see Sun Xiaochun and Jakob Kistemaker, The Chinese Sky during the Han: Constellating Stars and Society (Leiden: Brill, 1997), Appendix II, 164. It is the canopy of the throne of the heavenly emperor, to whom Central Yellow (Zhonghuang 中黃) certainly alludes.

31 Xiyue gong 西岳公, the god of the Western Peak (Mount Hua 華山 in modern Shaanxi). It is the title of the immortal Huanglu zi 黃盧子, alias Ge Yue 葛越; see the Monograph on the Western Peak, Mount Hua (Xiyue Huashan zhi 西獄華山誌), compiled by Wang Chuyi 王處一 and prefaced (1183) by Liu Dayong 劉大用, "Yellow God Gorge" ("Huangshen gu" 黃神谷), CT 307, 10b-11a. For a hagiography of Ge Yue, see Robert F. Campany, To Live as Long as Heaven and Earth: A Translation and Study of Ge Hong's Traditions of Divine Transcendents (Berkeley and Los Angeles: University of California Press, 2002), 303. On the five sacred mountains of China, see n. 41 below.

32 CT 1185, 17.21a-22b. Cf. Ware, Alchemy, Medicine, Religion, 300. 
Five figures follow this section. The Great Peace Symbol being the third symbol mentioned in the preceding passage, I assume it corresponds to the third figure in the series (see Figure 1). ${ }^{33}$ One of the most conspicuous features in this illustration is the Northern Dipper (Beidou 北斗) constellation along its top and right sides. This constellation, which is composed of the seven brightest stars in the Ursa Major of Western astronomers, is the "most prominent circumpolar asterism" of the starry sky and, as such, it has fascinated the Chinese from the earliest times. ${ }^{34}$ In Taoism, it has played a central role in the meditation practices, liturgy, and artefact design of many traditions. ${ }^{35}$ The three dots forming an upside-down "V" symbolize another constellation, also part of the Western Ursa Major and also a noted visual feature recurring in Taoism, the Three Terraces (Santai 三臺), and the two lines on its sides are probably also stellar references. ${ }^{36}$ The remaining visual components also belong to the kind of symbolic grammar analysed by Monika Drexler. For example, the item “曰” (a horizontally stretched $r i$ 日) could either symbolize the Five Agents, or the beasts emblematic of the Five Agents, or the sun or the moon, or a deity of the sun or of the moon. ${ }^{37}$ The semiotics of individual components is liable to change from one specimen to the next and each tradition certainly used its own symbolic grammar. ${ }^{38}$

\section{2. "Great Peace Symbol” (seventh-ninth century?)}

Moving forward a few hundred years, we meet a second specimen in the Divine Symbols of the Five Peaks of the Most High Numinous Treasure of Pervading Mystery (Taishang dongxuan Lingbao wuyue shenfu 太上洞玄靈寶五獄神 符), an anonymous, undated collection, which could be a Tang 唐 dynasty (618-907) archaistic composition (CT 390). ${ }^{39}$ The first eleven symbols are introduced by citations of an earlier collection, now lost, the Diagrams of the Divine Immortals (Shenxian tu 神仙圖). This generic title refers to a nomenclature of visual materials which have been traced back to the library of Ge Hong's master

33 These five figures are preceded by a short sentence, "Missing are those four symbols" 關 此四符也 (17.21a), probably a later commentary interpolated in the main text, as noted in Wang Ming 王明 (ed.), Baopu zi neipian jiaoshi 抱朴子内篇校釋, second edition (Beijing: Zhonghua shuju, 1985), 322, n. 101. Ware omits the sentence in his translation.

34 Quoting p. 212, n. 5, of David W. Pankenier, "A brief history of Beiji 北極 (Northern Culmen), with an excursus on the origin of the character di 帝”, Journal of the American Oriental Society, 124/2, 2004, 211-36.

35 For meditation, see Robinet, Méditation taoïste, 298-327. For liturgy and symbol design, see Drexler, Daoistische Schriftmagie, 89-95; Mollier, Buddhism and Taoism Face to Face, 134-73; and Li Juntao 李俊濤, “Daojiao futu de xingchen fuhao tanmi” 道教 符圖的星辰符號探秘, Zhonghua wenhua luntan 中華文化論壇, 1, 2008, 85-90.

36 Drexler, Daoistische Schriftmagie, 31 and 85-9. For the astronomical location of the Three Terraces, see Sun and Kistemaker, The Chinese Sky during the Han, 153.

37 Drexler, Daoistische Schriftmagie, 51, 67-8, and 99-101.

38 Drexler's sources mainly pertain to the Song 宋 era (960-1279) Heart of Heaven (Tianxin 天心) tradition of exorcism. See Poul Andersen's review article, "Taoist talismans and the history of the Tianxin tradition", Acta Orientalia, 57, 1996, 141-52. 


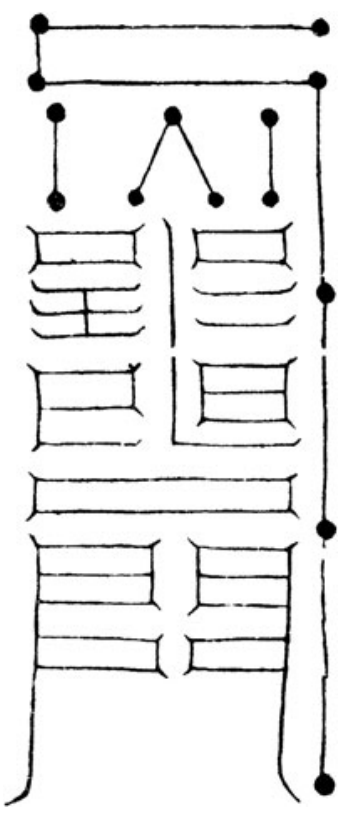

Figure 1. [“Li Er's Great Peace Symbol”?] (CT 1185, 17.21b)

Zheng Yin 鄭隱 (c. 215-c. 302). ${ }^{40}$ Our second specimen is thus linked to the same Southern tradition as the first one.

The present collection unfolds the following twenty-six symbols, with transmission lines or dedicated guidelines for use or worship: the five symbols of the Five Peaks; ${ }^{41}$ six (sic) symbols of the Perfected of the Five Peaks (wuyue zhenren 五茯真人); a “White Tiger Symbol” (“Baihu fu”白虎符), with a rite ascribed to the three mythical rulers Yao 堯, Shun 舜 and Yu 禹; “Five stabilization symbols" ("Wuzhen fu" 五鎮符); a "Great Peace Symbol", with a rite ascribed to Yao; seven "Awe-inspiring Virtue Symbols" ("Weide fu” 威德符); and a "Five Generals Symbol" ("Wu jiangjun fu”五將軍符) with a military function. The whole sequence may be interpreted as a liturgy for conformity to cosmic cycles, Earth stability, and the pacification of the empire.

The drawing of this second Great Peace Symbol (see Figure 2) is composed of four rectangular spaces arranged into columns of two, without any obvious resemblance to our first artefact. It is followed by this text:

40 Stephen R. Bokenkamp, "Sources of Ling-pao scriptures", in Strickmann (ed.), Tantric and Taoist Studies in Honour of R.A. Stein, 2, 434-86, at pp. 458-60.

41 Wuyue 五获, five sacred mountains corresponding to the four cardinal directions and the centre, and whose geographical identification varied over the centuries before being fixed under the Sui 隋 dynasty (581-618); see Cui Xiuguo 崔秀國 et al., Wuyue shihua 五获 史話 (Beijing: Zhonghua shuju, 1982). On the sacred mountain of the South, see James Robson, Power of Place: The Religious Landscape of the Southern Sacred Peak (Nanyue 南获) in Medieval China (Cambridge, MA: Harvard University Asia Center, 2009). 

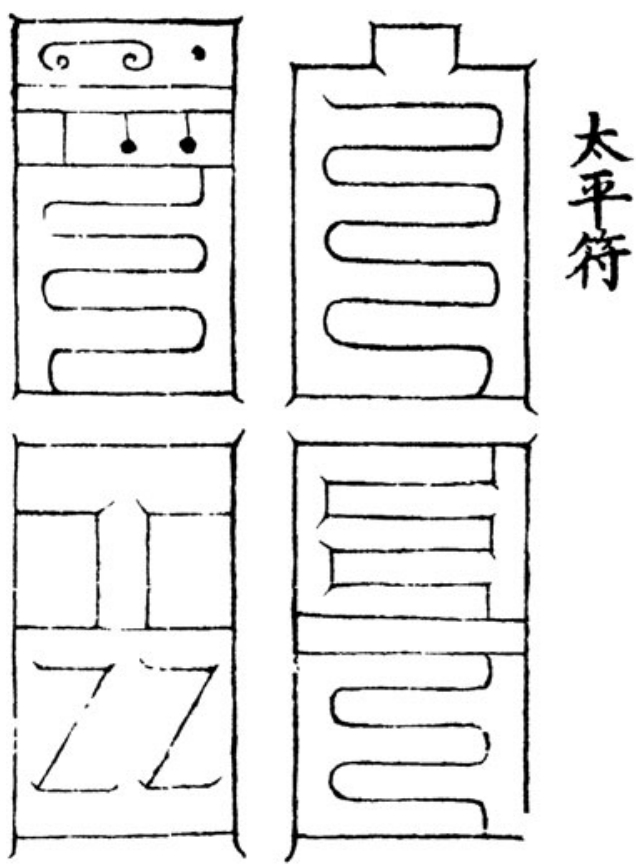

Figure 2. "Great Peace Symbol” (CT 390, 11b-12a)

堯鳳凰元年正月甲子, 師巫咸受堯天子. 王有天下五获, 四瀆，山川常 禁司神，天有厭鎮. 以威四海，服八夷，兵寇不起，疾疫自除. 與響相 應, 神常助之. 祭法: 用三牲物牛角五寸, 羊角七寸, 䐗百二十斤; 清酒 五斛，黄抙米飯，果實; 十二香火，毎面三枚; 壇面二十八丈；白茅爲 萹，長二尺二寸. 亦用粢米五斗; 千二百杯，面四百杯；二丈八尺長竿， 立之中庭; 十二丈旛, 四方等; 五大案二十四杯, 合百二十杯; 五色相 校; 書繒四丈一尺. 清人, 公子, 內臣臨祭三日受戒. 元年三月, 祭受福 氣見; 三月,令平氣見; 三年, 天下太平.

In the first year of the Fenghuang [era] of Yao's [rule], during the normative (=first) month, on the first day of the sexagesimal cycle, Wuxian $^{42}$ the master recognized Yao as Son of Heaven. The king (Yao) had the Overseers of the Deities ${ }^{43}$ of the Five Peaks, Four

42 According to the Shiji, 3.100, Wuxian 巫咸 was the chamberlain of King Taiwu 太戊, seventh ruler of the Shang 商 or Yin 殷 dynasty (c. 1570-1045 BC), called Dawu 大戊 in late Shang sacrificial inscriptions; see David N. Keightley, "The Shang: China's first historical dynasty", in Michael Loewe and Edward L. Shaughnessy (eds), The Cambridge History of Ancient China: From the Origins to 221 B.C. (Cambridge: Cambridge University Press, 1999), 234-5, Figure 4.1. Later on, the name of Wuxian was attached to an astrological tradition.

43 Sishen 司神, a verb-object compound which may also be translated as "to control deities". Yao would then have prohibited an action rather than a body of religious specialists. 
Rivers, ${ }^{44}$ mountains and waterways of the realm permanently prohibited, thereby bringing stability to Heaven. By inspiring awe to the four seas and subduing the Eight Barbarians, ${ }^{45}$ [he] prevented armed brigands from rising, and epidemics spontaneously dissipated. Responding like an echo, the gods assisted him constantly. Sacrificial method: Use the three domestic animals [under the species of] a five-inch long ox horn, a seven-inch long ram horn, and 120 catties $^{46}$ of pork [meat]; 5 bushels ${ }^{47}$ of sacrificial wine; yellow sacrificial millet, husked and cooked, and fruits; twelve sticks of incense, three on each side; an altar, 28 toises $^{48}$ a side; weedy grass ${ }^{49}$ for the mats, [each] two feet and two inches long. Also use 5 pints $^{50}$ of husked sacrificial millet; 1,200 cups - 400 cups a side; a bamboo pole, two toises and eight feet ${ }^{51}$ long, erected in the centre of the area; 12 toises $^{52}$ of banner arranged on the four sides; five large tables [with] 24 cups [each] - 120 cups in all; [soil] of the five colours in matching proportions; ${ }^{53} 4$ toises and 1 foot $^{54}$ of calligraphy silk. The pure ones, the noble scions, ${ }^{55}$ and the court dignitaries attended the sacrifice and received the precepts for three days. In the third month of the first year, the sacrifice obtained the appearance of blessed pneumata. ${ }^{56}$ In the third month, it made the pneumata of Great Peace appear. In the third year, the realm $[\mathrm{knew}]$ Great Peace. ${ }^{57}$

This text opens and closes as a narrative of sovereignty, while the intervening part unfolds detailed preparations for a rite whose ultimate purpose is to establish Great Peace, a potent concept evoking a golden age of perfect universal

$44 S i d u$ 四瀆, the four major rivers of China - the Yellow River; the Yangtze; the Huai 淮, a tributary of the Yangtze; and the Ji 濟, today corresponding to the lower course of the Yellow River.

45 Bayi 八夷, a generic reference to the non-Chinese rather than to a specific ethnicity.

46 About 80 kilograms. A capacity unit, the catty (jin 斤) varied in time.

47 About 300 litres. The bushel ( $h u$ 斛) corresponds to 10 pints (dou 斗).

48 About 85 metres. The toise (zhang 丈) corresponds to 10 feet (chi 尺).

49 Baimao 白茅, a herbaceous plant: Imperata cylindrica (L.) P. Beauv.

50 About 30 litres.

51 About eight-and-a-half metres.

52 About 36 metres.

53 Explaining the ritual production of symbols designed to stabilize each of the five sectors, the preceding five sections of the text give in turn prominence to soil ( $t u$ 土) the colour of the overcoming agent - green soil to stabilize the Centre, and so forth - over the four others. Presumably, this coloured soil was to be spread over the surface of the altar.

54 About 12.5 metres.

55 Gongzi 公子, an archaic term; see Charles O. Hucker, A Dictionary of Official Titles in Imperial China (Stanford: Stanford University Press, 1985), 296, no. 3494.

$56 Q i$ 氣 is the primary constituent of the universe and of all things in Chinese metaphysics, and a Chinese word for which no entirely satisfying English rendition seems to exist; see Ulrich Libbrecht, "Prāna = pneuma = ch'i?", in Wilt L. Idema and Erik Zürcher (eds), Thought and Law in Qin and Han China: Studies Dedicated to Anthony Hulsewé on the Occasion of His Eightieth Birthday (Leiden: Brill, 1990), 42-62.

57 CT 390, 12a-b. This source mentions the "Great Peace Symbol" solely in the title preceding both the illustration and the text. 
harmony and its re-actualization. ${ }^{58}$ This ritual performance by a mythical Chinese figure at the beginning of his rule goes far beyond the production of a talisman. The name of the illustrated symbol has clearly retained one of the early meanings of $f u$, "token" - a token of the advent of Great Peace.

In mythical context, the rite marked the founding of a new political and religious order. In the present liturgy, by preparing the rite as prescribed and performing it, the officiating Taoist re-enacts a founding liturgy of power and thereby restores cosmic equilibrium.

Our final three specimens come from sources which date from within a century or two and appear in the context of Taoist liturgy as performed by a trained officiant on behalf of an individual or a community. They share an internal use, as all three were to be physically ingested during the religious service.

\section{3. "Great Peace Symbol" (thirteenth century)}

The third specimen is found in the Jade Mirror of Numinous Treasure (Lingbao yujian 靈寶玉鑑), an undated, anonymous manual, whose contents borrow from different Taoist traditions (CT 547). Incomplete, its present edition seems not to predate the thirteenth century. ${ }^{59}$ Preceding the work, the Lingbao yujian mulu 靈 寶玉鑑目錄, its table of contents (CT 546), mentions a “Great Peace Symbol” under the heading of chapter 18. This chapter belongs to a series of five consecutive chapters (17-21) identically titled "Class: Flying deities visiting the [Heavenly] Emperor" (“Feishen yedi men” 飛神謁帝門) 60 and devoted to divine petitioning from different traditions, most notably Orthodox Unity (Zhengyi 正一). ${ }^{61}$ In the usual bureaucratic fashion, these rites consist of sending a divine emissary to petition the supreme deity on behalf of the supplicant. The "Great Peace Symbol" first appears in the description of an Orthodox Unity "Method for submitting petitions and performing ablutions" ("Shangzhang muyu fa”上章沐浴法). This ritual sequence is thus introduced:

凡爲國䓛民上章拜表，非一日一時所可行之事. 須於日前，調運身心， 令神䲷泰定. 沐浴七日，服五神符，誦五神呪；七日，服太平符；七日， 服通神符. 遇立夏日，伐霜木造丹元君一身，如真人狀，長三寸廣七分， 同沐浴入室. 行持四十九日. 次服心章符. 庶通達誠意，上合天心，元 氣自升矣.

58 Barbara Hendrischke, The Scripture on Great Peace: The Taiping jing and the Beginnings of Daoism (Berkeley: The University of California Press, 2006), 4-13.

59 Lowell Skar, "Lingbao yujian 靈寶玉鑑: Jade Mirror of the Numinous Treasure", in Fabrizio Pregadio (ed.), The Encyclopedia of Taoism (London: Routledge, 2008), 679-80. Lagerwey (Companion, 1018-1021, nos 546-7) parallels the text to other more or less contemporary summae liturgicae but refrains from proposing a precise date.

60 CT 546, 15 b.

61 The early Taoist Church referred to its founding revelation as the "Newly appeared way of the covenantal authority of Orthodox Unity", xinchu zhengyi mengwei zhi dao 新出正 一盟威之道. “Orthodox Unity” later became the usual label of the Church's teachings, scriptural corpus, and liturgy, and by metonymy of the whole Heavenly Master tradition. 
Generally, submitting a petition or addressing a memorandum on behalf of the dynasty or the people is not a matter executable in a single day or moment. [The priest] must, before the [foreseen] day, moderate bodily activities and adopt the right mental attitude, so as to make divine pneumata stable. Perform ablutions for seven days, [then] absorb a Five Gods Symbol and chant the invocation to the Five Gods. ${ }^{62}$ [After] seven [more] days, absorb a Great Peace Symbol. [After] seven [more] days, absorb a Symbol for Transmission to the [Heart] God. [When you] come across the first day of Summer, ${ }^{63}$ cut down a jujube tree and model a figure of the Lord of Cinnabar Prime, similar to a Perfected, three inches long and seven-tenths [of an inch] wide; together with [this figure], perform ablutions and enter the oratory. ${ }^{64}$ Keep practising for forty-nine days. Next, absorb a Heart Petition Symbol. Should [you] convey intentions with sincerity, [they will] unite with the mind of Heaven above, and primordial pneuma will spontaneously ascend. ${ }^{65}$

Extending over several months, this ritual preparation demands a remarkable investment both in time and discipline. It includes the oral absorption of four symbols (discussed and given illustrations in the chapter) and the chanting of invocations. On a given calendar conjunction, the priest is requested to carve a small wooden figure of his or her own most vital corporeal god, the Lord of Cinnabar Prime (Danyuan jun 丹元君), the deity of the organ heart. ${ }^{66}$

62 Further on (CT 547, 18.24b), the invocation complementing the "Five Gods Symbol" ("Wushen fu" 五神符) names these corporeal deities: 1. Great Unity (Taiyi 太乙), located in the Upper Prime (Shangyuan 上元), here the upper Cinnabar Field (dantian 丹田); 2. the Director of Destiny (Siming 司命), in the Middle Prime/Cinnabar Field; 3. Peach Vigour (Taokang 桃康), in the Lower Prime/Cinnabar Field; 4. Primordial Blossom (Yuanying 元英), a probable misspelling for the more frequently encountered Blossomless (Wuying 无英); and 5. White Prime (Baiyuan 白元). The last two entities are deprived of location. These names already appear in early medieval Taoist sources, some of which locate the fourth entity in the liver and the fifth in the lungs; see Fabrizio Pregadio, "Early Daoist meditation and the origins of inner alchemy", in Penny (ed.), Daoism in History, 121-58. On Taiyi, also spelled “太-”, see Sarah Allan, "The Great One, water, and the Laozi: new light from Guodian", T'oung Pao, 89/4-5, 2003, 237-85.

63 Lixia ri 立夏日, forty-five days before the Summer solstice (xiazhi 夏至). Lixia 立夏 is the seventh of the twenty-four divisions of the Chinese tropical year; see Joseph Needham with Wang Ling, Science and Civilisation in China, 3, Mathematics and the Sciences of the Heavens and the Earth (Cambridge: Cambridge University Press, 1959), 405, Table 35.

$64 R u$ shi 入室, in which shi stands for jingshi 靖室.

65 CT 547, 18.23b-24a. My punctuation of this passage remains tentative.

66 Further characterized as being the "primordial god" (yuanshen 元神) of the officiating priest, a fraction of primordial pneuma descended into his or her body, and the "ruler of [his or her] natal destiny" (benming zhu 本命主), this personal deity should be worshipped on each birthday (CT 547, 18.26b). Interestingly, Cinnabar Prime is also one of the "Taoist names" of the fifth star of the Northern Dipper constellation, Alioth ( $\varepsilon$ Ursae Majoris), according to Edward H. Schafer, Pacing the Void: T ang Approaches to the Stars (Berkeley and Los Angeles: University of California Press, 1977), 51, Table 1. The astronomical name of Alioth is Jade Transverse (Yuheng 玉衡). 


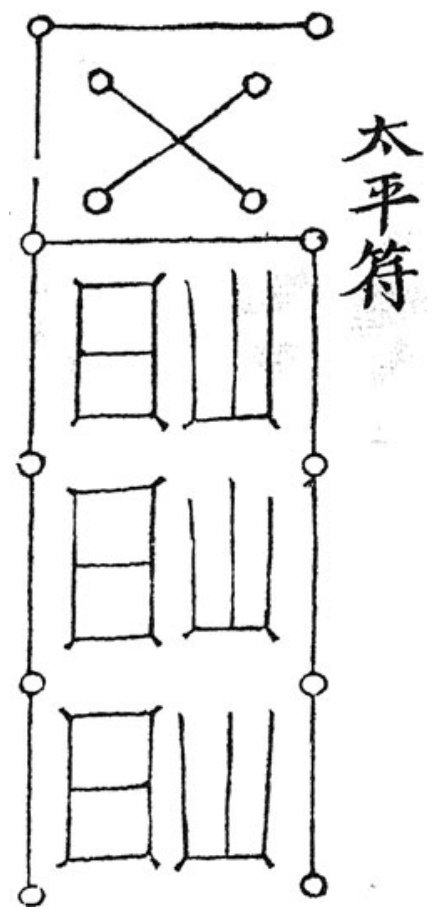

Figure 3. "Great Peace Symbol" (CT 547, 18.25a)

Next comes the recipe of a seven-ingredient decoction designed for the ritual bath where the ablutions should take place (jian yutang 煎浴湯) every day at the seventh ( $w u$ 午) hour (noon). The recipe is followed by an invocation to be chanted, and by the illustrations of the "Five Gods Symbol", to be swallowed (tun 吞), and of a "Symbol to Purify the Unclean [while] Performing Ablutions" ("Muyu jinghui fu" 沐浴淨穢符), to be dissolved (hua 化) in the bath. Each symbol comes with an invocation. Then the illustration of the "Great Peace Symbol" is given (see Figure 3). This symbol shares with our former two specimens a vertical structure and, with the first one, the schematic rendition of the Northern Dipper in the same location. However, the seven extra dots form different groupings - an X-shaped group of four inside the "bowl" of the Dipper, and three linked dots connected to the lower left angle of the "bowl". The former group could be a representation of the twenty-eight Lodges (xiu 宿) organized into four series of seven. ${ }^{67} \mathrm{On}$ the basis of the first specimen, the latter group seems to be a linear, "flattened" rendition of the Three Terraces constellation. The central part combines items similar to the regular Chinese characters $r i$ 日 and shan 山, both featured three times - here again, these are not characters but visual elements pertaining to a symbolic grammar. The latter (“山”) may symbolize various deities of the Taoist pantheon. ${ }^{68}$ Next comes a set of guidelines:

67 Drexler, Daoistische Schriftmagie, 52.

68 According to Drexler, Daoistische Schriftmagie, 50, 53 and 73, the god Heavenly Unity (tianyi 天一), or the four Grand Emperors (dadi 大帝) of Jade Clarity (Yuqing 玉清), 
右符以燈心霜湯化服. 想丹元君㝠坐綘宮, 黑念三天隱諱, 泓, 澄, 明, 八十一徧, 乗三素雲上升玉堂玉帝訣. 呵氣于身, 次調息, 咽津九過.

The preceding symbol is to be absorbed, dissolved in a decoction of lamp wick $^{69}$ and jujube. Think about the Lord of Cinnabar Prime quietly sitting in the Crimson Palace. ${ }^{70}$ Silently recite the hidden, avoided names of the Three Heavens, Immense, Clear, and Luminous, ${ }^{71}$ eighty-one times, and the Instructions of the Jade Emperor ${ }^{72}$ for Riding the Clouds of the Three Original Colours ${ }^{73}$ and ascending to the Jade Hall. Breathe the air out of the body, then regulate breathing and swallow saliva nine times. ${ }^{74}$

This ritual segment, included in the liturgical sequence of ablutions, includes visualization, recitation and breathing practices.

\section{4. "Great Peace Symbol Opening the Heart" (mid-fourteenth century)}

A few decades later we meet a fourth specimen in the Pearls Bequeathed from the Sea of Rites (Fahai yizhu 法海遺珠), a liturgical compendium in 46 chapters (CT 1166). A preface by one Zhang Shunlie 章舜烈, where the year 1344 is mentioned, has led modern scholarship to ascribe the whole work to the fourteenth century. This compendium reflects one of the traditions collectively known as Thunder Methods (Leifa 雷法), which developed during the eleventh century. ${ }^{75}$

Upper Clarity (Shangqing), Great Clarity (Taiqing 太清), and Purple Tenuity of the North Pole (Beiji ziwei 北極紫微), with their immortal retinue, or the three Offices of Heaven (Tianguan 天官), Earth (Diguan 地官), and Water (Shuiguan 水官); according to Liu and He, "Daojiao fuyin jiedu (1)", 22, and Liu, "Daojiao fuyin jiedu (2)", 51, the Three Clarities (Sanqing 三清) - the Jade Clarity, Upper Clarity, and Great Clarity just mentioned.

69 Dengxin 燈心 refers to a medicinal substance obtained from a species of rush, dengxin cao 燈心草 (Juncus effusus L. var. decipiens Buchan), whose therapeutic uses are expounded in the "Swamp Herbs" ("Xicao" 隰草) sub-category of the "Herbs" (“Cao" 草) category in the Systematic Materia Medica (Bencao gangmu 本草綱目), compiled between 1552 and 1578 by Li Shizhen 李時珍 (1518-93), 15.98a-99b (Siku quanshu edition).

70 Jianggong 綘宮, the organ heart.

71 Alternative esoteric names of the Three Heavens are given in other texts such as the Tang Secret Avoided Names of the Three Heavens of Pervading Truth (Dongzhen Santian mihui 洞真三天祕諱), CT 1350, 1a-b: "Bulwark" (Fang 防) for Clear Tenuity Heaven (Qingwei tian 清微天) above; “Origin” (Yuan 元) for Yu's Leftover Heaven (Yuyu tian 禹餘天) in the middle; and "Mound of Virtue" (Deqiu 德丘) for Great Scarlet Heaven (Taichi tian 太赤天) below. For the date of that source, see Companion, 491-92, no. 1350.

72 Yudi 玉帝, also known as the Jade August One (Yuhuang 玉皇), located in the Jade Hall (yutang 玉堂) mentioned in the same sentence, is the highest god in the late Taoist pantheon after the Three Clarities. Perhaps derived from popular religion, it was given an increasingly prominent status in Taoism from the late Tang or early Song era onwards. See H.Y. Fêng, "The origin of Yü Huang", Harvard Journal of Asiatic Studies, 1/2, 1936, 242-50.

$73 S a n s u$ 三素, a varying combination from a group comprising purple ( $z i$ 紫), the imperial colour par excellence, and some of the emblematic colours of the Five Agents.

74 CT 547, 18.25a-b.

75 On this category of exorcist rites, see Florian C. Reiter, Basic Conditions of Taoist Thunder Magic (Wiesbaden: Harrassowitz, 2007). 
It is assumed to document practices prevalent to the south of the River Yangtze from the twelfth to the fourteenth century. ${ }^{76}$

In chapter 19 of the compendium, the last ritual sequence, called "Secret method for petitions and memorials of the Numinous Treasure" ("Lingbao zhangzou mifa" 靈寶章奏祕法), includes a shorter variant of the Orthodox Unity "Method for submitting petitions and performing ablutions" appearing in the source of our third specimen. This ritual sequence opens with a set of prescriptions and an invocation:

凡未拜章, 七日之前, 齋戒三日, 入靖不交人事. 每日作用心章符, 太平 符, 伏章符, 向旺方以淨水吞之. 服時, 含符於口中, 舌拄上腭, 仰面看 東方，以鼻引青䲷，在口存青乭; 次仰看天上，以鼻引紅䲷入口; 次俯 看地下，以鼻吸地中黄乭入口; 存三色互, 混合併在口中，團成一丸燦 爛, 光芒如日; 存符在光中, 以水吞下. 毎日服符之次, 持念通章呪曰: 心中神, 丹元君, 長三寸, 廣七分, 着朱衣, 繫綘裙, 乗威德, 顯至靈, 通造化, 達至真, 住心中, 莫離身. 外有急事, 疾來告人; 今有心章, 伏 請報應, 急急如律令.

Generally, seven days before presenting a petition, observe abstinence for three days, enter the oratory, ${ }^{77}$ and do not meddle in human affairs. Each day, prepare for use a Heart Petition Symbol, a Great Peace Symbol, and a Deferential Petitioning Symbol. Swallow them with pure water, facing the dominant direction. ${ }^{78}$ Place the symbols to absorb in the middle of the mouth, press the tongue against the palate, raise the face and look to the East; inhale green pneuma through the nose and keep it in the mouth. Next, raise the head and look to Heaven above; inhale red pneuma through the nose, and [make it] enter the mouth. Next, incline the head and look to Earth below; through the nose, inhale yellow pneuma from the centre of Earth and [make it] enter the mouth. Visualize the pneumata of the three colours and merge [them by] assembling [them] in the middle of the mouth and rolling [them] into a brilliant pill, resplendent as the sun. Visualize the symbols in the middle of the light, and swallow [them] with water. Each day, after absorbing the symbols, observe the recitation of the [following] Invocation for the Transmission of the Petition:

"God in the centre of [my] heart, Lord of Cinnabar Prime, three inches long and seven-tenths [of an inch] wide, wearing a vermilion-red tunic and a crimson-red skirt, controlling awe-inspiring virtue and manifesting the supremely numinous, understanding creative transformation and reaching supreme perfection. Stay in the centre of [my] heart and do not leave [my] body. There is a pressing matter outside, in haste [I] come to call upon you. Now here is a Heart Petition, deferentially [I] ask [you] to report in answer. Promptly, pursuant to the statutory orders." 79

76 According to Companion, 1090-91, no. 1166.

$77 R u$ jing 入靖, in which jing stands for jingshi 靖室.

78 Wang fang 旺方 is the direction determined by the season - and the agent dominating accordingly - or perhaps the sexagesimal binomial of the day.

79 CT 1166, 19.20a-21a. The closing injunctive formula, "Promptly, pursuant to the statutory orders" (jiji ru lü ling 急急如律令), is a well-documented borrowing from the early 
Both the set of prescriptions and the invocation to the Heart God have already appeared in the source of our third specimen, albeit differently ordered within the liturgical sequence. ${ }^{80}$ The size of the wooden figure to be carved in our third source here applies to the Heart God itself as visualized by the officiant. The illustration of the Heart Petition Symbol and the ritual guidelines for its production and absorption lead to the illustration of a "Great Peace Symbol Opening the Heart" ("Kaixin taiping fu" 開心太平符) (see Figure 4). This illustration is mostly identical to the third artefact, except that in the upper register, the four dots joined by two strokes forming an $\mathrm{X}$ are lacking, rather a deliberate alteration than the accidental result of a defective master woodblock or printing process.

The phrases "Opening the Heart" and "Great Peace" from the name of the symbol occur again in the rhymed “Imperious Invocation” (Chi zhou 敕呪) subsequently given:

\begin{tabular}{|c|c|}
\hline 神符 & [I] ingest the divine symbol and \\
\hline 自招真靈 & $\begin{array}{l}\text { Communicate with the Perfected and Numina, } \\
\text { beckoning them. }\end{array}$ \\
\hline 百神走使 & All the gods enter [my] service, \\
\hline 徹中情 & Harmoniously penetrating [my] innermost conscience. \\
\hline 甲肅衞 & The Six Jia, ${ }^{81}$ [my] Majestic Guardsmen, ${ }^{82}$ \\
\hline 淵清清 & Are unfathomable and crystal-clear \\
\hline 行元䂞 & The Five Agents and primordial pneuma, \\
\hline & Fathomless and inconspicuous. \\
\hline 末始 & Chaotic, not yet begun, \\
\hline אלנדור & All beings refrain from taking shape. \\
\hline & By perceiving forms $[\mathrm{I}]$ already know \\
\hline 地神經 & The divine scriptures of Heaven and Earth. \\
\hline & [They] call [this symbol] "opening the heart" and \\
\hline 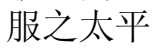 & By Absorbing it one [brings forth] Great Peace. \\
\hline & Reaches the knowledge of naturalness, ${ }^{83}$ \\
\hline & And ascends, flying, to the Purple Court. ${ }^{84}$ \\
\hline
\end{tabular}

imperial administration; see Seidel, "Traces of Han religion in funeral texts found in tombs".

80 Cf. CT 547, 18.26a-27a.

81 Liujia 六甲, stellar deities possibly named after the homonymous six-star constellation located in the circumpolar area of the nocturnal sky known as the Purple Tenuity (Ziwei); see Sun and Kistemaker, The Chinese Sky during the Han, 165. In ritual context, they derive from the six divine generals of early medieval Heavenly Master Taoism and, connected with the Northern Dipper as well as the binomial corresponding to the adept's year of birth in the sexagesimal cycle, preside over lifespan duration; see Mollier, Buddhism and Taoism Face to Face, 114-20.

82 Suwei 肅衞, another official term; see Hucker, A Dictionary of Official Titles in Imperial China, 461 , no. 5855.

83 Ziran 自然, also often translated as "spontaneity", here an aspect of the Way.

84 Ziting 紫庭 is the seat of the heavenly emperor, more or less equivalent to the Purple Tenuity (Ziwei) already encountered. 


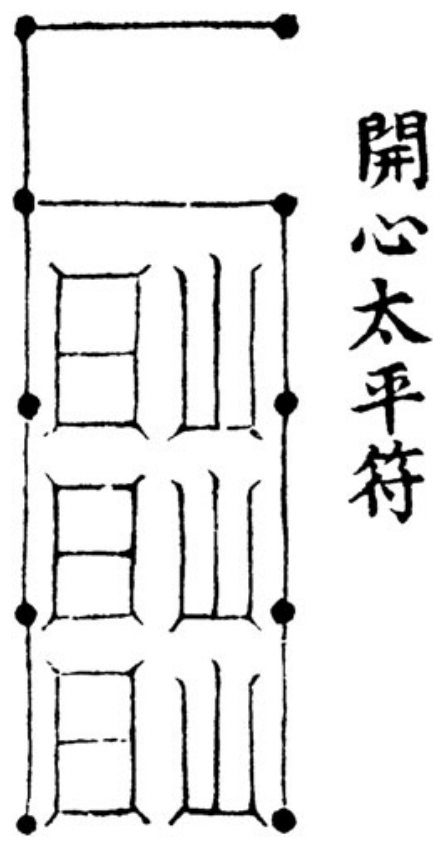

Figure 4. "Great Peace Symbol Opening the Heart" (CT 1166, 19.21a-b)

急急如上帝律令

Promptly, pursuant to the statutory orders of the Emperor on High. ${ }^{85}$

Thus "to open the heart" means to interiorize the pantheon and to become aware again of one's inner primordial chaotic state, corresponding to an early stage in cosmogony, filled with limitless potential. The chapter ends without further mention of a Great Peace Symbol, but all these elements will also be found in the source of the fifth specimen.

\section{5. "Heart-Opening Great Peace Symbol for Communicating with the Perfected and Reaching the Numina" (late fourteenth-century edition)}

The source of our last specimen is the Major Method of the Upper Scripture of Universal Salvation of the Numinous Treasure (Lingbao wuliang duren shangjing dafa 靈寶无量度人上經大法), a long synthesis of salvation rites for the living and the dead, in 72 chapters (CT 219). Despite the presence of two in-text references to the Ming dynasty ( $d a$ Ming guo 大明國) inviting to date the canonical edition to the late fourteenth century at the earliest, Lagerwey believes that the original version of the text was put together around $1200 .{ }^{86}$

86 Lagerwey suggests that the author could be a disciple of Ning Benli 寧本立 (1101-81), the synthesizer of Northern and Southern traditions of exorcism (see Companion, 
The "Section: Circulating Gods to Join the Effulgences" ("Yunshen hejing pin” 運神合景品, Chapters 43-4) describes a ritual programme involving the circulation of the corporeal pantheon visualized by the officiating Taoist within his or her body, as he or she performs an internalized rite of divine petitioning justified by the identity of both the inner and outer divine spheres. ${ }^{87}$ Chapter 43 displays a "Heart-Opening Great Peace Symbol for Communicating with the Perfected and Reaching the Numina" ("Tongzhen daling kaixin taiping fu" 通 真達靈開心太平符). Except for a single stroke on the left of the figure, we easily recognize our third specimen. That missing stroke seems to confirm that the three linked dots on the lower left side of the figure, independent from the Northern Dipper in the present rendition, are indeed a linear rendition of the Three Terraces (see Figure 5).

Written in reduced-size characters, a subheading adds that this symbol must be “drawn in vermilion red [ink on] yellow plain silk" (zhushu huangsu 朱書黃 素). Practical prescriptions of this sort are frequently encountered in Taoist sources presenting symbols and blank forms of various religious documents. In the present case, red is the emblematic colour of the South and the organ heart in the correlative system of the Five Agents; and yellow, one of the basic colours of the medium on which such symbols are usually drawn.

Like our previous two specimens, this "Great Peace Symbol" was intended for internal use. Its illustration is followed by an "invocation" to be uttered by the officiating Taoist as he or she “absorbs the symbol” (“Fufu zhou” 服符 呪). Composed in rhymed, four-syllable verse, this invocation probably served as model for the "Imperious Invocation" ("Chi zhou") from the preceding source, translated above. ${ }^{88}$ Concise guidelines close this invocation:

呪里, 吒齒三通, 以符安口内方, 存互吞之.

The invocation being completed, strike [your] teeth together three times, place the symbol inside [your] mouth, hold [your] breath, and swallow it. ${ }^{89}$

1028-32, no. 219). For a later date taking into account the references to the Ming (CT 219, 43.5b and 55.8a), see Ren Jiyu 任純愈 and Zhong Zhaopeng 鍾肇鵬 (eds), Daozang tiyao 道藏提要, third edition (Beijing: Zhongguo shehui kexue, 2005), 15456 , no. 218.

87 “True Symbols of the Eight Effulgences" (“Bajing zhenfu” 八景真符) are introduced in Chapter 43, with complete guidelines (CT 219, 43.7b-8a); the "Eight Effulgences" therein seem to refer to gods coming to inform the officiating Taoist of the outcome of the petitioning. The next section, titled "Gods Ascending to Enter the Wondrous" ("Shengshen rumiao" 昇神入妙), stresses the importance of practising "circulating gods to join the effulgences" (yunshen hejing) for having one's petitions successfully transmitted to the heavenly emperor (CT 219, 43.8a-b). For jing 景 as referring both to stellar and bodily entities, see pp. 174-5 of Michel Strickmann, "On the alchemy of T'ao Hung-ching", in Holmes Welch and Anna Seidel (eds), Facets of Taoism: Essays in Chinese Religion (New Haven and London: Yale University Press, 1979), $123-92$.

88 CT 219, 43.5a-b. Cf. CT 1166, 19.21b-22a (half a dozen variants).

89 CT $219,43.5 b$. 


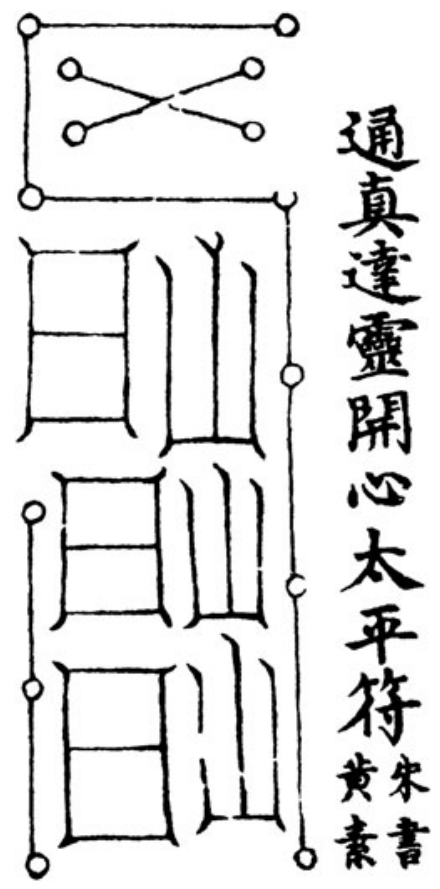

Figure 5. "Heart-Opening Great Peace Symbol for Communicating with the Perfected and Reaching the Numina" (CT 219, 43.5a)

The chapter then turns to the Heart Petition - which we have met in the preceding two sources - a bureaucratic document the priest addresses to his or her heart god with the express order to messenger it to the upper deities. In reducedsize characters the detailed guidelines to ingest a Heart Petition (to be drawn using a blank form scrupulously reproduced in the text) are given, together with a "Great Peace Symbol": these are basically identical to those appearing in the source of the fourth specimen and, again, involve the visualization and inhalation of coloured pneumata. ${ }^{90}$ The major difference is that here, the sole symbol to be ingested, rather than three distinct symbols, is the "Great Peace Symbol". More importantly, immediately following the ingestion of the Great Peace Symbol comes the swallowing of the petition itself, previously reduced to ashes (hui 灰):

其服心章, 以章灰入口, 一依符訣.

As regards the absorption of the Heart Petition, enter the ashes of the petition into [your] mouth and comply exactly with the instructions [for absorbing] the symbol. ${ }^{91}$ 
These guidelines lead to a "Spell for the Transmission of the Absorbed Petition to the Gods" (“Fuzhang tongshen zhu” 服章通神祝), which must have served as model for the "Invocation to the Lord of Cinnabar Prime" ("Danyuan jun zhou” 丹元君呪) from the source of the third specimen, called in the source of the fourth specimen (translated above) "Invocation for the Transmission of the Petition" (“Tongzhang zhou” 通章呪). ${ }^{92}$ The text then moves on to describe further ritual segments of this layered liturgy, but our "Great Peace Symbol" does not appear again.

\section{Epilogue}

Due to its peculiar focus and its chronological extension, this survey has inherent limitations. It is not possible to state with utmost certainty whether these different symbols were ever used or not, and assuming they were, by whom and with which result. Also impossible to prove is that the various Great Peace Symbols on the one hand, and some of the practices advocated in the Great Peace Scripture (Taiping jing 太平經) on the other hand, reflect a single tradition. The hypothesis is all the more tempting since Ge Hong lists a Great Peace Scripture in the inventory of his master Zheng Yin's library. ${ }^{93}$ Indeed, the ritual guidelines included in the sources of the last three specimens echo the visualization of colours in one's corporeal space, as described in a late product of the Great Peace tradition, the Great Peace Scripture: Secret Directives of the Saintly Lord (Taiping jing shengjun mizhi 太平經聖君祕旨), a short text based on ancient material but compiled in the late Tang dynasty or soon after (CT 1102). ${ }^{94}$ In that particular context as well as in later internalized liturgy, however, Great Peace denotes a personal experience, a state of grace only vaguely reminiscent of the collective, eschatological aspiration it used to encapsulate in the early Great Peace tradition. ${ }^{95}$

And yet, such practices already existed in early medieval Taoist communities. Texts, of which comparatively old versions subsist, such as the well-known Scripture of the Yellow Court (Huangting jing 黃庭經), explain how to visualize corporeal entities organized and depicted in accordance with the correlative framework of the Five Agents. ${ }^{96}$ Furthermore, there is evidence - including in the textual sources of the last three specimens - that some symbols, once integrated into elaborate and at least partly internalized liturgies, did retain a basic talismanic function, albeit accessory in many cases. And of course, the rite of divine petitioning itself - a borrowing, as we have seen, from imperial bureaucratic procedures, and attested in Taoism since the early medieval era - remained

92 Cf. CT 547, 18.26b, and CT 1166, 19.20b-21a. There are only a few variant readings between both versions.

93 CT 1185, 19.3a.

94 On which see Grégoire Espesset, "Les Directives secrètes du Saint Seigneur du Livre de la Grande paix et la préservation de l'unité", T oung Pao, 95/1-3, 2009, 1-50.

95 See Hendrischke, The Scripture on Great Peace, 13-6 and 47-54.

96 Companion, 96-97, no. 332, and 184-85, no. 331. 
prominent throughout the history of Taoism. ${ }^{97}$ Thus did early forms of religiosity adapt to historical changes.

Can we prove the existence of any historical relationship between the first two specimens, quite dissimilar, and the three later ones, which are evidently variants of the same ritual tool? To this point, Mollier's treatment of Buddhist and Taoist symbols provides us with a crucial source, the Marvellous Scripture for Prolonging Life and Adding to the Account, Spoken by the Most High Lord Lao (Taishang Laojun shuo changsheng yisuan miaojing 太上老君説長生益 等妙經), a late-seventh-century Taoist text (CT 650). ${ }^{98}$ The purpose of this text is to offer the adept the protection and help of life-governing gods, in particular the generals of the Six Jia 六甲, in order to extend his or her lifespan. ${ }^{99}$ To this effect, the text presents a series of fifteen symbols, beginning with a "Heart-opening symbol" ("Kaixin fu" 開心符) closely resembling the last three specimens of our survey (see Figure 6). Of course, a third dot would seem to be missing on the left-side vertical stroke, three stars of the Northern Dipper are not dotted on the right-side vertical stroke, and the central area includes a supernumerary “山” as well as the item “甲”, the latter naturally representing the Six Jia. ${ }^{100}$ These discrepancies notwithstanding, in all likeliness this "Heart-Opening Symbol" is the prototype of our last three "Great Peace Symbols".

The first specimen known to Ge Hong was a talisman properly speaking, a portable device endowed with specific powers, almost like an amulet. Unlike its later morphotypes, but much like the symbols dealt with by Ge Hong, the "Heart-Opening Symbol" above was to be carried by the adept and therefore had an unquestionable talismanic function. But to that function a ritual dimension had already been added: the efficiency of the symbol depended on the adept reciting the scripture and worshipping it. ${ }^{101}$ The last three specimens, with their standardized morphology, were certainly designed by adapting the general morphology and - in the fourth and fifth cases - borrowing the name of that

97 For a synthesis focused on the early medieval era, see Lü Pengzhi, "Daoist rituals", in John Lagerwey and Lü Pengzhi (eds), Early Chinese Religion. Part Two: The Period of Division (220-589 AD) (Leiden: Brill, 2010), 1245-349.

98 Mollier, Buddhism and Taoism Face to Face, 106-9. Catalogues dated to 695 and 730 mention a Buddhist version of this text, known from Dunhuang manuscripts. In addition to CT 650 and its Buddhist adaptation, nearly identical, the Canon has a second Taoist version, the Marvellous Scripture of Divine Symbols for Adding to the Account, Spoken by the Most High Lord Lao (Taishang Laojun shuo yisuan shenfu miaojing 太上老君説 益等神符妙經), CT 672. Though different, the series of symbols included in CT 650 and CT 672, according to Mollier, may "form part of a ritual ensemble" (p. 109).

99 Suan 算, the "account" in the text title just translated, refers to an individually allotted capital of time units determining effective life duration; the value of a unit seems to have varied over time and with authors. For a few examples in medieval sources, see pp. 21-9 of Grégoire Espesset, "Criminalized abnormality, moral etiology, and redemptive suffering in the secondary strata of the Taiping jing", Asia Major, Third Series, 15/2, 2002, 1-50. For medieval Taoist and Buddhist strategies to increase this capital, see Mollier, Buddhism and Taoism Face to Face, 100-33 (Chapter 3: "Augmenting the life account").

100 Drexler, Daoistische Schriftmagie, 116.

101 Mollier, Buddhism and Taoism Face to Face, 113-4. 


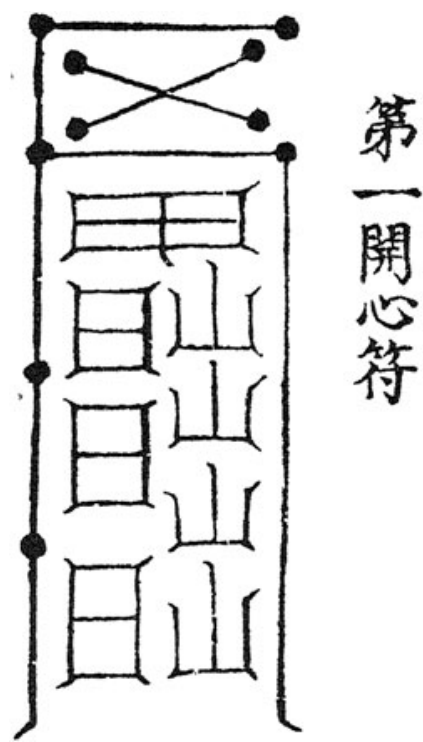

Figure 6. "Heart-Opening Symbol” (CT 650, 6a)

earlier "Heart-Opening Symbol". This borrowing may have been prompted by the lasting popularity the "Divine symbols for adding to the account" seem to have enjoyed. ${ }^{102}$ But other sources may have been used as well - other "Heart-Opening Symbols" such as those preserved in the Taoist Canon, and which, though morphologically unrelated to our specimens, were also designed for absorption ( $f u$ 服) by swallowing (tun 吞). ${ }^{103}$ No wonder our second specimen was ignored by the designers of these last three "Great Peace Symbols", if it was not simply unknown to them: its purpose, unlike that expected from common talismans, was far too macrocosmic to satisfy individual practitioners who were looking for personal devices they would combine into ritual sessions in the framework of layered liturgical programmes.

102 Mollier, Buddhism and Taoism Face to Face, 132-3.

103 For a Heart-opening symbol also ingested for divine petitioning, see the mid-twelfth-century Orthodox Rites of the Heart of Heaven of Upper Clarity (Shangqing Tianxin zhengfa 上清天心正法), edited by Deng Yougong 鄧有功 (1210-79?), CT 566, 6.5a-b. Other Heart-opening symbols appear in the Upper Clarity Instructions to be Kept in Hand (Shangqing wozhong jue 上清握中訣), ascribed to Tao Hongjing 陶弘景 (456-536) but certainly later, CT 140, 2.16a-b; and the anonymous, Southern Song 南宋 (1127-1279) or later Master Guigu's Numinous Text of the Quintessence of Heaven (Guigu zi tiansui lingwen 鬼谷子天髓 靈文), CT 867, 2.12b-13a. 